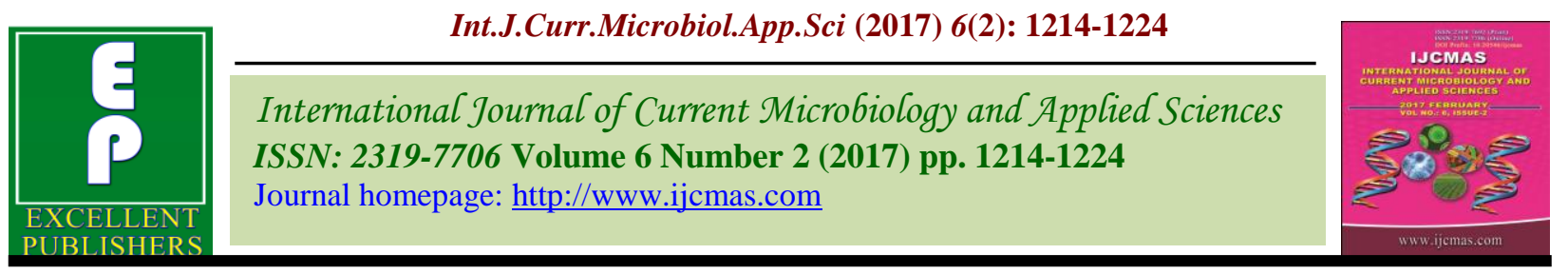

Original Research Article

http://dx.doi.org/10.20546/ijcmas.2017.602.138

\title{
In silico Identification and Characterization of Conserved miRNAs and their Targets in Pigeon pea (Cajanus cajan L.) Expressed Sequence Tags
}

\author{
Akula Dinesh $^{1 *}$ and More Yogeshwar ${ }^{2}$ \\ ${ }^{1}$ Department of Genetics and Plant Breeding, UAS, Raichur, 584102, India \\ ${ }^{2}$ Department of Plant Pathology; PDKV, Akola, Maharastra, India \\ *Corresponding author
}

\begin{abstract}
A B S T R A C T
MicroRNAs (miRNAs) are highly conserved class of short endogenous non-coding small

\begin{tabular}{l}
\hline Key w or d s \\
MicroRNA, \\
Pigeon pea, \\
EST, Gene \\
expression, \\
In silico. \\
\hline Article Info \\
\hline $\begin{array}{l}\text { Accepted: } \\
\text { 22 January } 2017 \\
\text { Available Online: } \\
\text { 10 February } 2017\end{array}$ \\
\hline
\end{tabular}

RNA molecules of about 18-22 nucleotide in length. MicroRNAs negatively regulate the gene expression by degrading target mRNA. In the present study, comparative genomic based approach was used to identify and characterize new conserved microRNAs in "orphan legume crop" pigeon pea (Cajanus cajan L.) using expressed sequence tags (ESTs) by in silico method. A total of 4,621 unique previously reported microRNAs were used for homology search in 25,576 ESTs of pigeon pea for identifying conserved miRNAs. The results upon stringent selection found five conserved miRNAs namely ccamiR6483, cca-miR5219, cca-miR393a, cca-miR395a, cca-miR169b belonging to five different families. The target analysis through psRNATarget server found $27 \mathrm{mRNA}$ targets which code for eukaryotic translation initiation factor 6 (EIF-6)-like protein, apyrase-like protein, ferric reductase, ATP sulfurylase, CCAAT-box transcription factor complex WHAP12, Lipoxygenase-9, Transport inhibitor response 1, and MYB transcription factor MYB102 which play an important role in response to both biotic and abiotic stresses. Our results have laid the foundation for further research on miRNAs, which will lead to understand the gene silencing mechanisms at post transcriptional level for various stresses.
\end{abstract}

\section{Introduction}

Pigeon pea (Cajanus cajan L.) is an often cross pollinated legume crop $(2 \mathrm{n}=2 \mathrm{x}=22)$ with genome size $808 \mathrm{Mb}$ conferring 48,680 genes. In India, pigeon pea is cultivated in an area of 3.88 mha contributing to total production of $3.29 \mathrm{mt}$ with average productivity of $849 \mathrm{~kg} / \mathrm{ha}$ (Agricultural statistics at a glance, 2014). Pigeon pea serve has a multipurpose crop with unique benefits like firewood, fence, thatch and making baskets from its byproducts apart from economic yield. The decomposition of fallen leaves will enrich soil with nutrients and also symbiotic nitrogen fixation increases fertility (Varshney et al., 2010). The nutritional benefits include $45 \%$ dietary fibers, $23 \%$ protein, $7 \%$ calcium, trace amounts of thiamin, riboflavin, and niacin. Despite of many advantages, pigeon pea has remained "orphan legume crop" with less genetic improvement (Varshney et al., 2009). Recognizing its importance, substantial amount of genomic resources have been generated, largely owing to the efforts of 
Indo-US Agricultural Knowledge Initiative (AKI), NSF and GCP funded projects and its genome sequence has been drafted (Varshney et al., 2010; Dutta et al., 2011; Bohra et al., 2011). To exploit advantages from pigeon pea, the knowledge about the genetic basis of yield, quality and stress tolerance is important for genetic improvement. Under such circumstances microRNAs (miRNA) are one of the major players in controlling biotic and abiotic stress responses in plants (Schwab et $a l$. , 2005). The miRNAs are approximately 21-nucleotide (nt) noncoding small RNAs that are encoded by MIR genes located in the intergenic (between protein-coding genes) or intragenic regions (within protein-coding genes) on the chromosomes which play critical roles in gene regulation at the posttranscriptional level (Schwab et al., 2005; Unver et al., 2009; Yang et al., 2012).

The molecular mechanism of miRNAmediated gene expression involves perfect or near perfect complement with targeted mRNA sequences, and then degrade targeted mRNAs or repress mRNA translation (Bartel et al., 2004). The miRNAs are therefore negatively regulate the gene expression (Voinnet et al., 2009). A wide range of miRNAs have been discovered in model crops like arabidopsis, rice and maize which code for several developmental programs, such as root initiation and development, vascular development, leaf morphogenesis and polarity as well as floral differentiation (Marin et al., 2010; Donner et al., 2009; Mallory et al., 2004; Chuck et al., 2008).

Reviewing the important of miRNAs in plant development, many methods were developed to identify the miRNAs among them computational method was effective, quick and less time consuming. The biogenesis of miRNAs suggests that it is possible to find miRNAs by searching expressed sequence tags (ESTs) with known miRNAs. This method provided avenue for identification of conserved miRNAs based on comparative genomics in many species like Allium sativum, Camellia sinensis, Zea mays, Glycine maxand Gossypium herbacium (Panda et al., 2014; Das and Mondal, 2010; Zhang et al., 2006a; Liu et al., 2011; Boopathi and Pathmanaban, 2012).

As mentioned above, pigeon pea an "orphan legume crop" despite of many advantages with less information was registered about miRNAs. This article mainly provides genetic basis for different responses in pigeon pea to stress and enhance the genetics of the crop. The identification of new miRNAs was done through in silico mining in expressed sequence tags (ESTs). Our efforts resulted in identification of five novel microRNAs in pigeon pea.

\section{Materials and Methods}

\section{Collection of miRNA sequences and ESTs of pigeon pea}

To search potential new miRNA in pigeon pea expressed sequence tags (ESTs), the sequences of previously known plant mature miRNA sequences from viridaeplantae kingdom were downloaded from miRBase release 21 (http://wwwmirbaseorg/ftpshtml). The total count of plant mature miRNA sequences was around 8486 which includes lots of similarities and duplicates.

The redundancy in miRNA sequences were removed by cd-hit online sever with Sequence identity cut-off of 1 which means $100 \%$ similarity between the sequences. This resulted in 4621 unique miRNA sequences. These miRNA sequences were BLASTed to assembled EST sequences of pigeon pea (Cajanus cajan L.). The EST sequences (25,576 as on 2014) were downloaded from NCBI's dbEST database (http://www.ncbi. nlm.nih.gov/). 


\section{Processing of pigeon pea ESTs in to contigs and singletons}

All downloaded ESTs are partial sequences of a gene which consist of wide range of contamination like, polyA tails, repetitive regions, vector sequences and more over many of the ESTs are duplicates. All redundant and poor quality sequences were subjected to EGassembler online server, which processes the data in series of sequence cleaning, repeat masking, vector masking, organelle masking and finally sequence assembly by using CAP3 to give contigs $(1,378)$ and singletons $(14,814)$ with all parameter kept default (Masoudi-Nejad et al., 2006). These contigs and singletons represent the non redundant part of downloaded ESTs.

\section{Precursor miRNA prediction}

The processed unique miRNA reference set was used for homology search in pigeon pea contigs and singletons using BLASTn option in BioEdit software version 7.2.5 (Hall et al., 1999). The blast parameters like e-value was kept 1, word match size 11 and matchmismatch score $(1,-4)$ and filtered low complexicity regions. All those pigeon pea EST sequences which are having query coverage of 95 to $100 \%$ and with mismatch less than 2 with miRNA sequences were selected and forwarded for further analysis to remove protein coding sequences among the identified ESTs. Since all the miRNA genes are non protein coding (Lee et al., 1993), BLASTx online server was used to remove the protein coding sequences through blasting of precursor's to non redundant (NR) protein data base of pigeon pea. The non coding sequences were selected based on criteria, E value less than $\mathrm{e}^{-5}$ along with the identity percent less than 25 (Dehury et al., 2013). The workflow for identification and characterization of new miRNAs were presented in figure 1 .
The leftover non coding sequences were used for prediction of precursor miRNA using Zuker folding algorithm in MFOLD software version $\quad 3.2 \quad$ (http://mfoldrnaalbanyedu $/ ? \mathrm{q}=$ mfold/rna-folding-form) with all default parameters (Zuker, 2003). The precursor sequences were searched at 50 nucleotides upstream or downstream from the location of mature miRNAs with an increament of 10 nucleotides. A stringent selection criteria was followed to select novel miRNA (Zhang et $a l ., 2005)$. The selection criteria in order to identify the appropriate hair pin structure includes 1) The minimum length of the premiRNAs to be $60 \mathrm{nt}, 2$ ) The pre-miRNA should fold into an appropriate stem loop hairpin secondary structure, 3) The miRNA/miRNA* duplex i.e., the mature miRNA sequence and its opposite miRNA strand (miRNA*) should not have more than $7 \mathrm{nt}$ mismatches (Das and Mondal, 2010) 4) The mature miRNA sequence should be placed in one arm of the hairpin structure, 5) The A+U content should be within $30-70 \%$ and 6) Predicted secondary structure should have higher minimal folding free energy index (MFEI)

$\mathrm{MEFI}=[(\mathrm{MEF} /$ length of the RNA sequence $)$ $\times 100] /(\mathrm{G}+\mathrm{C}) \%$

\section{Target prediction}

The newly identified miRNA sequences were submitted to psRNA Target tool for target prediction (http://plantgrnnobleorg/psRNA Target/) by specifying search on Glycine max (soybean), unigene, DFCI Gene Index (GMGI), version 16.

The earlier reports have found that pigeon pea genome has high synteny relation with soybean genome (Varshney et al., 2011). All the parameters were kept constant except expected value 3 , to have good number of targets. 


\section{Functional annotation of target proteins}

The genome annotation of the identified targets was done by using QickGo (http://wwwebiacuk/ QuickGO) tool. Furthermore, three important components such as biological process, cellular component and molecular function associated with each GO term were retrieved The predicted miRNAs were named in accordance with miRBase (Griffiths-Jones et al., 2006).The mature sequences are designated 'miR', and the precursor hairpins are labeled as 'mir' with the prefix. In case of Cajanus cajan it will be cca-miR395a for homologue of sly-miR395a.

\section{Results and Discussion}

\section{In silico identification of novel miRNA}

A total of 25,576 ESTs of pigeon pea (Cajanus cajan) were assembled to form contigs $(1,378)$ and singletons $(14,814)$ which were used for identification of new miRNAs based on homology relationship with previously reported non redundant mature miRNAs. The BLASTn programme with specific parameters (see materials and method) led to detection of 7 ESTs (4 singletons and 3 contigs) showing conserved miRNAs sequence with mismatch less than 2 nucleotide (nt) with previous miRNAs. The BLASTx operation these 7 ESTs resulted in retrieving 5 ESTs sequences which do not code for any protein. These 5 EST sequences were analyzed for presence of characteristic secondary hairpin structure. All the five ESTs fold into appropriate secondary structure and proved to be new miRNAs in pigeon pea (Fig. 1). The size of the newly identified miRNAs was in range of $20 \mathrm{nt}$ to $22 \mathrm{nt}$ which are considered as ideal length for typical miRNA (Zhang et al., 2006a). The $\mathrm{A}+\mathrm{U}$ content ranged from $49 \%$ to $69 \%$ which is in agreement with Zhang et al., (2005) with an average of $58 \%$ and similarly the $\mathrm{G}+\mathrm{C}$ content ranged from $30 \%$ to $50 \%$ with an average of $41 \%$ (Table 1). The length of the precursor miRNAs ranged from 93 to $194 \mathrm{nt}$ with an average of $133 \mathrm{nt}$. The newly identified precursor miRNAs have minimum folding free energies (MFE) ranging from -74 to $-162 \mathrm{kcal} / \mathrm{mol}$ which are not in consistence with folding energies of tRNA $-275 \mathrm{kcal} / \mathrm{mol}$ and rRNA $-33 \mathrm{kcal} / \mathrm{mol}$ (Barozai et al., 2008). The Minimal folding free energy index (MFEI) and MFE have been considered as significant features that distinguish miRNAs from other non coding RNAs (rRNA, tRNA, mRNA). The MFEI of newly identified precursor miRNAs ranged from 0.97 to 5.2 which is significantly higher than that of tRNAs (0.64), rRNAs (0.59) and mRNAs (0.62-0.66) with an average of 2.4 proving that these newly identified miRNAs in pigeon pea are likely to be actual miRNAs than any other kind of non-coding RNA (Zhang et al., 2006b). All of above findings and analysis indicated that these five small RNAs were probably new miRNAs. The hairpin structure of newly identified miRNAs was presented in figure 2 .

\section{Computation based identification of putative target of new miRNAs}

Result from psRNATarget server showed that the newly identified miRNAs have 27 target mRNAs, which code for different proteins involved in metabolism, response to stress, transcriptional regulation, signal transduction, growth, development, sulfate assimilation, protein lipoylation, coenzyme and, oxidoreductase activity. Our results found that the cca-miR6483 has highest number of targets ie., 10 genes followed by cca-miR395a with 7 targets genes, cca-miR5219 (2 target genes), cca-miR169b (4 target genes) and ccamiR393a (4 target genes). In the present study, it was observed that, one miRNA has more than one target mRNA, which were in 
consistence with the reports of Boopathi and Pathmanaban (2012). The majority of targets genes includes enzymes $42.1 \%$ having important role in assimilation, resistance mechanisms and biological functions followed by genes for proteins $26.3 \%$, transcription factors $21.1 \%$, and transporters $10.5 \%$ (Fig. 3). Our results were in consistent with the studies of Nodine and Bartel (2010) and Das and Mondal (2010) who predicted that miRNAs regulates the functional genes in plants that were involved in various physiological processes, leaf morphogenesis, stress responses and signal transduction.
Many previous reports revealed that miRNAs of plants also regulates transcription factors (Lu and Yang, 2010). The newly identified miRNAs have following targets proteins, Eukaryotic translation initiation factor 6 (EIF6)-like protein, Apyrase-like protein, Protein kinase GhCLK1, Extensin, Ferric reductase, ATP sulfurylase, Dihydroflavonol-4reductase, CCAAT-box transcription factor complex WHAP12, Lipoxygenase-9, Transport inhibitor response $1,50 \mathrm{~S}$ ribosomal protein L20 and MYB transcription factor MYB102. The functional annotation of target mRNAs is presented in table 2 .

Table.1 Details of newly identified miRNAs in pigeon pea

\begin{tabular}{|c|c|c|c|c|c|c|c|c|c|c|c|c|}
\hline $\begin{array}{l}\text { New } \\
\text { miRNA }\end{array}$ & Source & Mature miRNA & $\begin{array}{l}\text { Homologue } \\
\text { miRNA }\end{array}$ & $\mathrm{L}$ & $\begin{array}{l}\text { PL } \\
\text { (nt) }\end{array}$ & $\begin{array}{l}\mathrm{LM} \\
(\mathrm{nt})\end{array}$ & $\begin{array}{l}\mathrm{NM} \\
\text { (nt) }\end{array}$ & $\begin{array}{c}\text { E- } \\
\text { value }\end{array}$ & $\begin{array}{c}(\mathrm{A}+\mathrm{U}) \\
\%\end{array}$ & $\begin{array}{l}(\mathrm{G}+\mathrm{C}) \\
\%\end{array}$ & $\begin{array}{c}\text { MFE } \\
(\Delta \mathrm{G}, \mathrm{kc} \\
\mathrm{al} / \mathrm{mol})\end{array}$ & MFEI \\
\hline $\begin{array}{c}\text { cca- } \\
\text { miR393a }\end{array}$ & $\begin{array}{c}\text { Contig1 } \\
015\end{array}$ & $\begin{array}{c}\text { CATCCAAAGGGA } \\
\text { TCGCATTG }\end{array}$ & $\begin{array}{c}\text { ppe- } \\
\text { miR393a }\end{array}$ & 3 , & 116 & 20 & 0 & $\begin{array}{c}6.00 \mathrm{E} \\
-06\end{array}$ & 49.1 & 50.9 & -90 & 2.2 \\
\hline $\begin{array}{c}\text { cca- } \\
\text { miR169b }\end{array}$ & $\begin{array}{c}\text { Contig1 } \\
261\end{array}$ & $\begin{array}{l}\text { TGAGCCAAGGAT } \\
\text { GGATTGCC }\end{array}$ & $\begin{array}{l}\text { vvi- } \\
\text { miR169b }\end{array}$ & $5^{\prime}$ & 165 & 20 & 1 & 0.006 & 59.4 & 40.6 & -161 & 2.4 \\
\hline $\begin{array}{c}\text { cca- } \\
\text { miR395a }\end{array}$ & $\begin{array}{c}\text { gi } \mid 25173 \\
9378\end{array}$ & $\begin{array}{l}\text { TGAAGTGTTTGG } \\
\text { AGGAACTCC }\end{array}$ & $\begin{array}{c}\text { sly- } \\
\text { miR395a }\end{array}$ & 3 ' & 93 & 21 & 1 & 0.012 & 63.4 & 36.6 & -74.1 & 2.1 \\
\hline $\begin{array}{c}\text { cca- } \\
\text { miR5219 }\end{array}$ & $\begin{array}{c}\text { gi } \mid 25173 \\
9202\end{array}$ & $\begin{array}{c}\text { TCATGGAATTTCA } \\
\text { GCTGCTGCA }\end{array}$ & $\begin{array}{c}\text { mtr- } \\
\text { miR5219 }\end{array}$ & 3 ' & 194 & 22 & 1 & 0.003 & 53 & 46.9 & -88.5 & 0.97 \\
\hline $\begin{array}{c}\text { cca- } \\
\text { miR6483 }\end{array}$ & $\begin{array}{c}\text { gi| } 28445 \\
6793\end{array}$ & $\begin{array}{c}\text { TATTGTAGAAATT } \\
\text { TTCAGGATC }\end{array}$ & $\begin{array}{c}\text { hbr- } \\
\text { miR6483 }\end{array}$ & 5 , & 101 & 22 & 0 & $\begin{array}{c}3.00 \mathrm{E} \\
-06\end{array}$ & 69.3 & 36.6 & -162 & 5.2 \\
\hline
\end{tabular}

The novel identified miRNAs were characterized in terms of $\mathrm{L}=$ Location of miRNA; PL = precursor miRNA length; $\mathrm{LM}=$ mature sequence length; $\mathrm{NM}=$ number of mismatches; $\mathrm{MFE}=$ minimal folding free energies; $\mathrm{MFEI}=$ minimal folding free energy index. 
Table.2 Prediction of miRNA target genes and their functional annotation

\begin{tabular}{|c|c|c|c|c|}
\hline miRNA ID & Target Acc & Target description & Target function & Biolobical process \\
\hline \multirow{5}{*}{ cca-miR6483 } & $\begin{array}{l}\text { TC436145 } \\
\text { TC465796 }\end{array}$ & $\begin{array}{l}\text { Eukaryotic translation initiation factor } 6 \\
\text { (EIF-6)-like protein }\end{array}$ & $\begin{array}{l}\text { Translation initiation factor } \\
\text { Ribosomal large subunit binding }\end{array}$ & $\begin{array}{l}\text { Mature ribosome assembly } \\
\text { Translation initiation }\end{array}$ \\
\hline & BE440256 & Apyrase-like protein & Hydrolase activity & Metabolic process \\
\hline & TC452083 & Protein kinase GhCLK1 & $\begin{array}{l}\text { Protein serine/threonine kinase activity } \\
\text { Transferase activity } \\
\text { Nucleotide binding }\end{array}$ & Protein phosphorylation \\
\hline & TC452253 & Extensin & Structural constituent of cell wall & Plant-type cell wall organization \\
\hline & TC473325 & Ferric reductase & Oxidoreductase activity & Oxidation-reduction process \\
\hline \multirow{2}{*}{ cca-miR5219 } & TC421771 & 60S ribosomal protein L9 & Structural constituent of ribosome & Translational elongation \\
\hline & TC423861 & Peptidyl-prolyl cis-trans isomerase & Isomerase activity & Protein peptidyl-prolyl isomerization \\
\hline \multirow{4}{*}{ cca-miR395a } & $\begin{array}{l}\text { BG789910 } \\
\text { TC432008 }\end{array}$ & ATP sulfurylase & Sulfate adenylyltransferase (ATP) activity & Sulfate assimilation \\
\hline & TC421817 & Plastidial lipoyltransferase 2 & Transferase activity & Protein lipoylation \\
\hline & GD787823 & Dihydroflavonol-4-reductase & Coenzyme binding & Metabolic process \\
\hline & BI426387 & Cytochrome P450 82A2 & Oxidoreductase activity & Oxidation-reduction process \\
\hline \multirow[t]{2}{*}{ cca-miR169b } & TC474864 & $\begin{array}{l}\text { CCAAT-box transcription factor complex } \\
\text { WHAP12 }\end{array}$ & $\begin{array}{l}\text { Sequence-specific DNA binding transcription factor } \\
\text { activity }\end{array}$ & Regulation of transcription \\
\hline & TC485068 & Lipoxygenase-9 & $\begin{array}{l}\text { Linoleate 13S-lipoxygenase activity, } \\
\text { Oxidoreductase activity }\end{array}$ & Oxidation-reduction process \\
\hline \multirow[t]{3}{*}{ cca-miR393a } & TC431817 & Auxin-responsive factor TIR1 protein & Inositol hexakisphosphate binding & Auxin-activated signaling \\
\hline & TC429100 & 50S ribosomal protein L20 & $\begin{array}{l}\text { Structural constituent of ribosome } \\
\text { Rrna binding }\end{array}$ & \multirow{2}{*}{$\begin{array}{l}\text { Translation } \\
\text { Biotic and abiotic stress }\end{array}$} \\
\hline & TC432236 & MYB102 & Sequence-specific DNA binding transcription factor & \\
\hline
\end{tabular}


Fig.1 Workflow for identification and characterization of new miRNAs and target genes in pigeon pea using ESTs

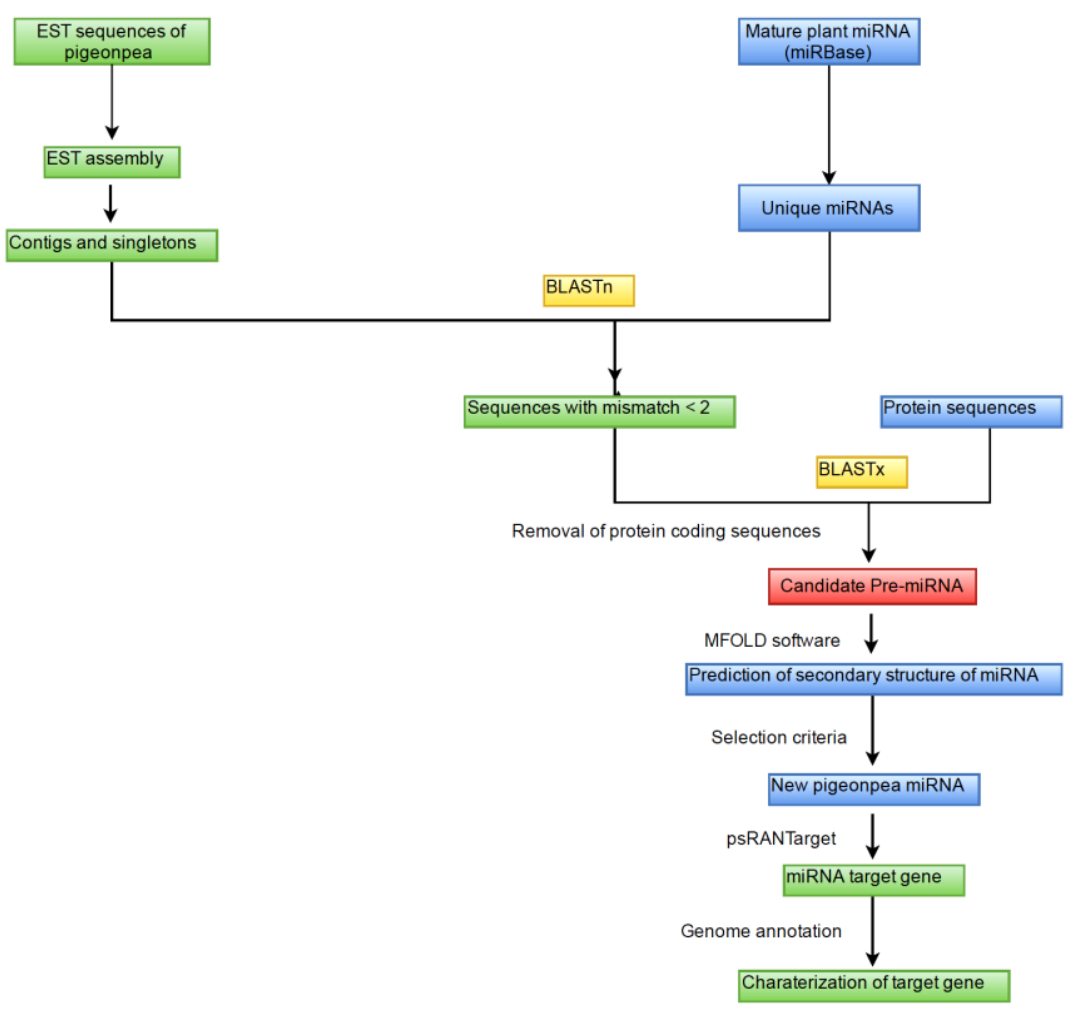

Fig.2 Secondary hair pin structure of newly identified miRNA in pigeon pea
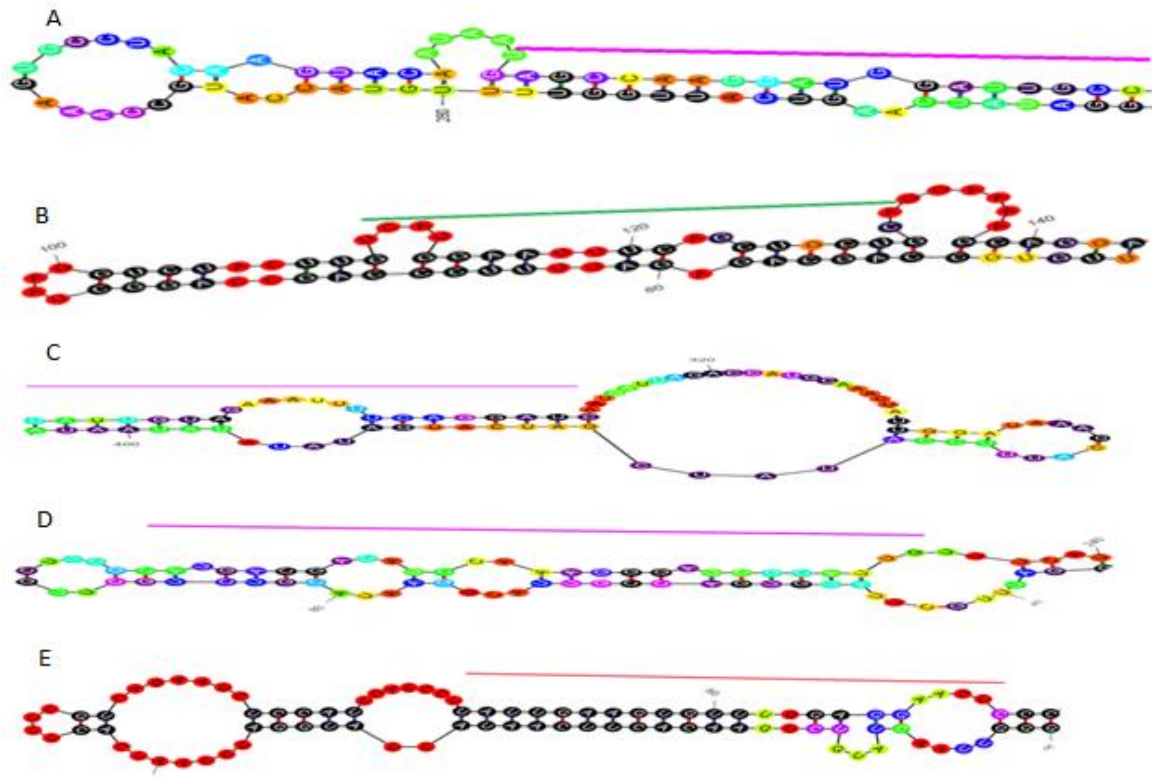

A) cca-miR169b, B) cca-miR5219, C) cca-miR6384, D) cca-miR393a, E) cca-miR395a. The pink color bar on the stem loop structure of miRNA indicates the mature miRNA sequences 
Fig.3 Major groups of miRNA targets

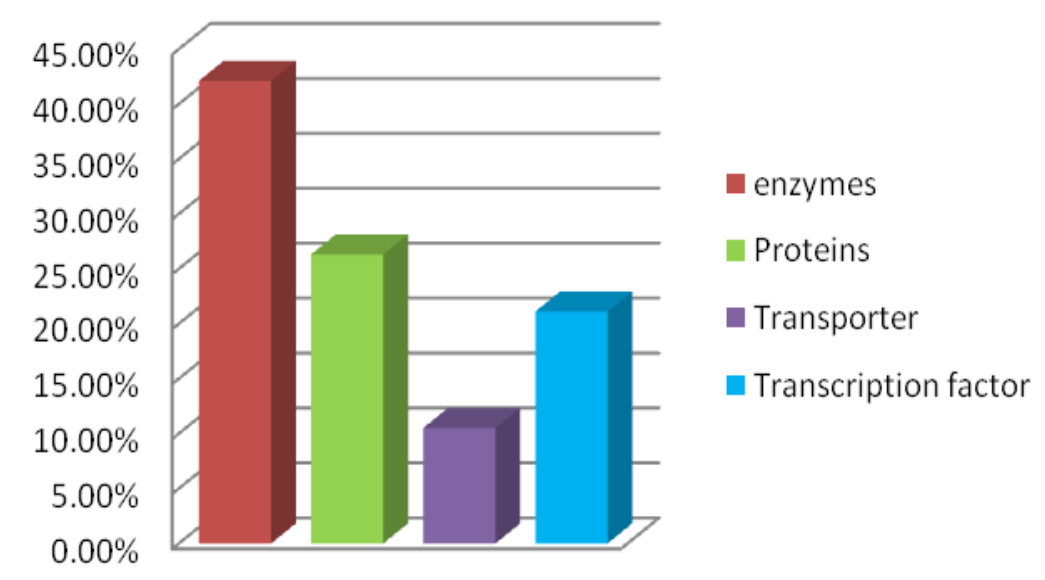

The cca-miR6483 targets multiple genes, it includes Eukaryotic translation initiation factor 6 (EIF-6)-like protein which has translation initiation factor activity, apyrase like protein, extensin and ferric reductase. In Arabidopsis and Rice EIF-6 has important role in embryogenesis (Kato et al., 2010). The enzyme apyrase play important role in plant nutrition and nodulation. In soybean, cell wall protein extensin composed of hydroxyprolinerich glycoproteins helps in cell wall metabolism and another enzyme ferric reductase regulated iron homeostasis in plants, thus helps in preventing Fe deficiency (Hong et al., 1994; O'Rourke et al., 2007).

The miRNA cca-miR395a targets ATP sulfurylase that involves in sulfur assimilation and improves nutrient content of the plant, Dihydroflavonol-4-reductase enzyme that controls seed coat and flower colour in soybean (Herrmann et al., 2014; Yan et al., 2014). The miRNA cca-miR5219 suppresses the expression of $60 \mathrm{~S}$ ribosomal protein L9 and peptidyl-prolyl cis-trans isomerase which help in translation elongation and protein peptidyl-prolyl isomerization respectively. The cca-miR169b negatively regulates transcription factors like CCAAT-box transcription factor complex WHAP12, nuclear transcription factor $\mathrm{Y}$ subunit A-3. The suppression of cca-miR169b leads to expression of Lipoxygenase-9, an important enzyme that confers resistance against the plant parasitic nematode, Heterodera glycines in soybean (Klink et al., 2009). cca-miR393a regulates transport inhibitor response 1(TIR1), involved in auxin-activated signaling pathway. The tir1mutants leads to abnormal hypocotyl elongation and lateral root formation (Ruegger et al., 1998). The miRNA cca-miR393a also regulates MYB102, which express under wide range of biotic and abiotic responses (Vos et al., 2006).

In conclusion we identified five new miRNAs in EST of pigeon pea having 27 mRNA targets, most of the them involved in stress responses, development, physiological process, protein phosphorylations and other metabolic processes This finding from our study leads to further investigation of miRNAs functions and regulatory mechanism under wide range of biotic and abiotic stress which leads to crop improvement of Pigeon pea "an orphan legume crop" 


\section{References}

Agricultural statistics at a glance. 2014. Directorate of Economics and Statistics, Ministry of Agriculture. Directorate of Economics and Statistics, Pp. 127.

Barozai, M.Y.K., Irfan, M. Yousaf, R. Ali, I. Qaisar, U. Maqbool, A. Zahoor, M. Rashid, B. Hussnain, T. and Riazuddin, S. 2008. Identification of micro-RNAs in cotton. Plant Physiol. Biochem., 46:739-751.

Bartel, D.P. 2004. MicroRNAs: genomics, biogenesis, mechanism, function. Cell, 116: 281-297.

Bohra, A., Dubey, A., Saxena, R.K., Penmetsa, V.R., Poornima, K.N., Kumar, N., Farmer, A.D., Srivani, G., Upadhyaya, H.D., Gothalwal, R., Ramesh, S., Singh, D., Saxena, K., Kishor, P.B.K., Singh, N.K., Town, C.D., May, G.D., Cook, D.R. and Varshney, R.K.2011. Analysis of BACend sequences (BESs) and development of BES-SSR markers for genetic mapping and hybrid purity assessment in pigeon pea (Cajanus spp). BMC Plant Biol., 56.

Boopathi, N.M. and Pathmanaban, R. 2012. Additional insights into the adaptation of cotton plants under abiotic stresses by in silico analysis of conserved miRNAs in cotton expressed sequence tag database (dbEST). African $J$. Biotechnol., 11:14054-14063.

Chuck, G., Meeley, R. and Hake, S. 2008. Floral meristem initiation and meristem cell fate are regulated by the maize AP2 genes ids1 and sid1. Development, 135: 3013-3019.

Das, A. and Mondal, T.K. 2010. Computational identification of conserved microRNAs and their targets in tea (Camellia sinensis). American J. Plant Sci., 1: 77-86.

Dehury, B., Panda, D., Sahu, J., Sahu, M.,
Sarma, K., Barooah, M., Sen, P. and Modi, M.K. 2013. In silico identification and characterization of conserved miRNAs and their target genes in sweet potato (Ipomoea batatas L) expressed sequence tags (ESTs). Plant Signaling and Behavior, 8: e26543.

Donner, T.J., Sherr, I. and Scarpelia, E. 2009. Regulation of preprocambial cell state acquisition by auxin signaling in Arabidopsis leaves. Development, 136: 3235-3246.

Dutta, S., Kumawat, G., Singh, B.P., Gupta, D.K., Singh, S., Dogra, V., Gaikwad, K., Sharma, T.R., Raje, R.S., Bandhopadhya, T.K., Datta, S., Singh, M.N., Bashasab, F., Kulwal, P., Wanjari, K.B., Varshney, R.K., Cook, D.R. and Singh, N.K. 2011. Development of genic-SSR markers by deep transcriptome sequencing in Pigeon pea [Cajanus cajan (L) Millspaugh]. BMC Plant Biol., 11: 17.

Griffiths-Jones, S., Grocock, J. R., Dongen, V. S., Bateman, A. and Enright, J. A. 2006. miRBase: microRNA sequences, targets and gene nomenclature. Nucleic Acids Res., 34: 1-8.

Hall, T.A. 1999. BioEdit: A user-friendly biological sequence alignment editor and analysis program for Windows 95/98/NT. Nucleic Acids Symposium Series, 41: 95- 98.

Herrmann, J., Ravilious, G. E., McKinney, S. E., Westfall, C. S., Lee, S. G., Baraniecka, P., Giovannetti, M., Kopriva, S., Krishnan, H. B. and Jez, J. M. 2014. Structure and mechanism of soybean ATP sulfurylase and the committed step in plant sulfur assimilation. J. Biol. Chem., 289: 10919-10929.

Hong, J.C., Cheong, Y.H., Nagao, R.T., Bahk, J.D., Cho, M.J. and Key, J.L. 1994. Isolation and characterization of three 
soybean extensin cDNAs. Plant Physiol., 104:793-806.

Kato, Y., Konishi, M., Shigyo, M., Yoneyama, T. and Yanagisawa S. 2010. Characterization of plant eukaryotic translation initiation factor 6 (eIF6) genes: The essential role in embryogenesis and their differential expression in Arabidopsis and rice. Biochem. Biophysical Res. Communications, 397:673-678.

Klink, V. P., Hosseini, P., Matsye, P., Alkharouf, N. W. and Matthews, B. F. 2009. A gene expression analysis of syncytia laser microdissected from the roots of the Glycine max (soybean) genotype PI 548402 (Peking) undergoing a resistant reaction after infection by Heterodera glycines (soybean cyst nematode). Plant Molecular Biol., 71: 525-567.

Lee, R. C., Feinbaum, R. L. and Ambros, V. 1993. The $\mathrm{C}$ elegans heterochronic gene lin-4 encodes small RNAs with antisense. Cell, 107: 309-321.

Liu, Y. X., Chang, W., Han, Y. P., Zou, Q., Guo, M. Z. and Li, W. B.. 2011. In silico Detection of Novel MicroRNAs Genes in Soybean Genome. Agri. Sci. China., 10:1336-1345.

Lu, Y. and Yang, X. 2010. Computational identification of novel MicroRNAs and their targets in Vigna unguiculata. Comparative and Functional Genomics, 128-297.

Mallory, A.C., Reinhart, B. J., JonesRhoades, M. W., Tang, G., Zamore, P. D., Barton, M. K. and Bartel, D. P. 2004. MicroRNA control of PHABULOSA in leaf development: importance of pairing to the microRNA 5' region. EMBO J., 23: 3356-3364.

Marin, E., Jouannet, V., Herz, A., Lokerse, A. S., Weijers, D., Vaucheret, H., Nussaume, L., Crespi, M. D. and Maizel, A. 2010. miR390, Arabidopsis
TAS3 tasiRNAs, and their auxin response factor targets define an autoregulatory network quantitatively regulating lateral root growth. Plant Cell, 22: 1104-1117.

Masoudi-Nejad, A., Tonomura, K., Kawashima, S., Moriya, Y., Suzuki, M., Itoh, M., Kanehisa, M. and Goto, E. T. 2006. EGassembler: online bioinformatics service for large-scale processing, clustering and assembling ESTs and genomic DNA fragments. Nucleic Acids Res., 34: 459-462.

Nodine, M. D. and Bartel, D. P. 2010. MicroRNAs prevent precocious gene expression and enable pattern formation during plant embryogenesis. Genes \& Development., 24:2678-2692.

O'Rourke, J. A., Charlson, D. V., Gonzalez, D. O., Vodkin, L. O., Graham, M. A., Cianzio, S. R. and Shoemaker, R. C. 2007. Microarray analysis of iron deficiency chlorosis in near-isogenic soybean lines. BMC Genomics, 8: 476.

Panda, D., Dehury, B., Sahu, J., Barooah, M., Sen, P. and Modi, M. K. 2014. Computational identification and characterization of conserved miRNAs and their target genes in garlic (Allium sativum L) expressed sequence tags. Gene., 537:333-342.

Ruegger, M., Dewey, E., Gray, W. M., Hobbie, L., Turner, J. and Estelle, M. 1998. The TIR1 protein of Arabidopsis functions in auxin response and is related to human SKP2 and yeast Grrlp. Genes \& Development., 12:198-207.

Schwab, R., Palatnik, J. F., Riester, M., Schommer, C., Schmid, M. and Weigel, D. 2005. Specific effects of microRNAs on the plant transcriptome. Developmental Cell, 8: 517-527.

Unver, T., Covert, D. N. and Budak, H. 2009. Review of current methodological approaches for characterizing microRNAs in plants. Int. J. Plant 
Genomics, 262-463.

Varshney, R. K., Penmetsa, R. V., Dutta, S., Kulwal, P. L., Saxena, R. K., Datta, S., Sharma, T. R., Rosen, B., et al., 2010. Pigeon pea genomics initiative (PGI): an international effort to improve crop productivity of pigeon pea (Cajanus cajan L.). Mol. Breeding, 26:393-408.

Varshney. R. K., Chen, W., Li, Y., Bharti, A. K., Saxena, R. K., Schlueter, J. A., Donoghue, M. T., Azam, S., Fan, G., et $a l .,$. 2012. Draft genome sequence of pigeon pea (Cajanus cajan), an orphan legume crop of resource-poor farmers. Nature Biotechnol., 30: 83-89.

Varshney, R. K., Close, T. J., Singh, N. K., Hoisington, D. A. and Cook, D. R. 2009. Orphan legume crops enter the genomics era. Curr. Opinion in Plant Biol., 12: 202-210.

Voinnet, O. 2009. Origin, biogenesis, and activity of plant microRNAs. Cell., 136: 669-687.

Vos, D.M., Denekamp, M., Dicke, M., Vuylsteke, M., Loon, V. L., Smeekens, S. C. and Pieterse, C. M. 2006. The Arabidopsis thaliana Transcription factor AtMYB102 functions in defense against the insect herbivore Pieris rapae. Plant Signal Behavior, 1: 305311.
Yan, F., Di, S., Rodas, F. R., Torrico, T. R., Murai, Y., Iwashina, T., Anai, T. and Takahash, R. 2014. Allelic variation of soybean flower color gene W4 encoding dihydroflavonol 4-reductase 2. $B M C$ Plant Biol., 14:58.

Yang, G.D., Yan, K., Wu, B.J., Wang, Y.H., Gao, Y.X. and Zheng, C.C. 2012. Genomewide analysis of intronic microRNAs in rice and Arabidopsis. $J$. Genetics, 91(3): 313-324.

Zhang, B. H., Pan, X. P. and Anderson, T. A. 2006A. Identification of 188 conserved Maize microRNAs and their targets. FEBS Lett., 580: 3753-3762.

Zhang, B. H., Pan, X. P., Cox, S. B., Cobb, G. P. and Anderson, T. A. 2006b. Evidence that miRNAs are different from other RNAs. Cellular and Mol. Life Sci., 63: 246-254.

Zhang, B. H., Pan, X. P., Wang, Q. L., Cobb, G. P. and Anderson, T. A. 2005. Identification and characterization of new plant microRNAs using EST analysis. Cell Res., 15:336-360.

Zuker. M. 2003. Mfold web server for nucleic acid folding and hybridization prediction. Nucleic Acids Res., 31: 3406-3415.

\section{How to cite this article:}

Akula Dinesh and More Yogeshwar. 2017. In silico Identification and Characterization of Conserved miRNAs and their Targets in Pigeon pea (Cajanus cajan L.) Expressed Sequence Tags. Int.J.Curr.Microbiol.App.Sci. 6(2): 1214-1224.

doi: http://dx.doi.org/10.20546/ijcmas.2017.602.138 